
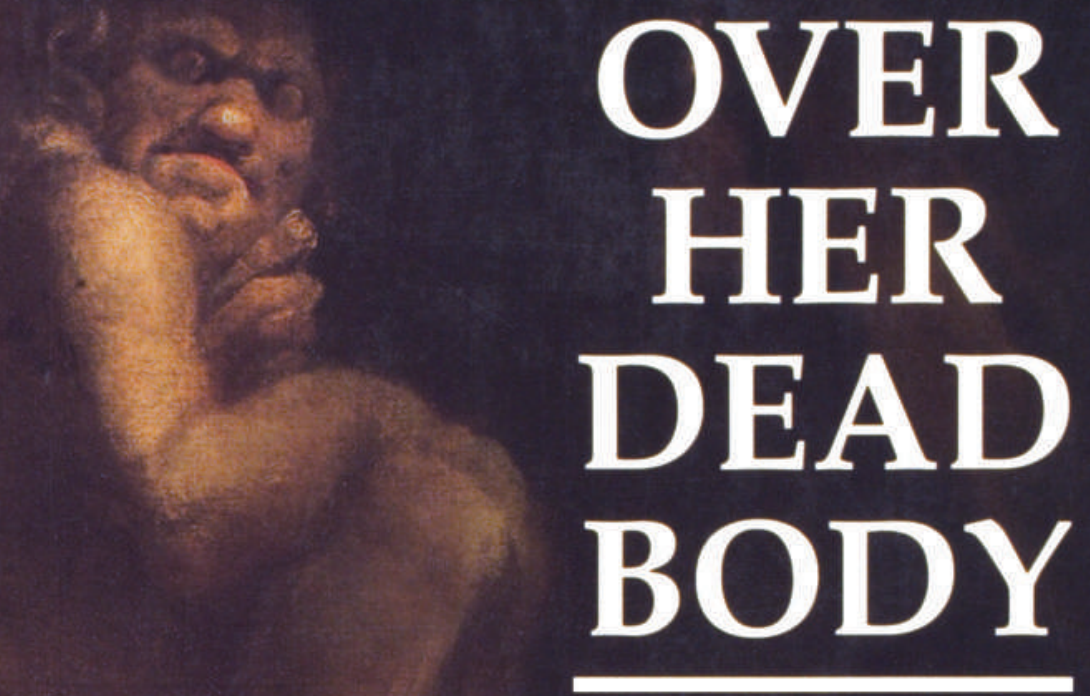

(2)

Death, femininity and the aesthetic

Elisabeth Bronfen

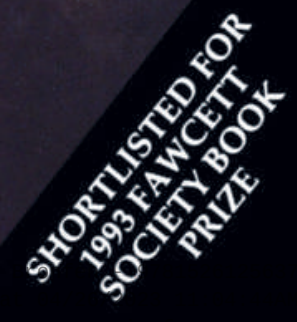




\section{OVER \\ HER \\ DEAD \\ BODY}


Yet, sister woman, though I cannot consent to find a Mozart or a Michael Angelo in your sex, cheerfully, and with the love that burns in depths of admiration, I acknowledge that you can do one thing as well as the best of us men - a greater thing than even Milton is known to have done, or Michael Angelo: you can die grandly, and as goddesses would die, were goddesses mortal.

Thomas de Quincey 


\section{OVER}

HER

\section{DEAD}

BODY

Death, femininity and the aesthetic

\section{Elisabeth Bronfen}

MANCHESTER

UNIVERSITY PRESS 
Copyright (C) Elisabeth Bronfen 1992

The right of Elisabeth Bronfen to be identified as the author of this work has been asserted by her in accordance with the Copyright, Designs and Patents Act 1988.

Published by Manchester University Press

Altrincham Street, Manchester M1 7JA, UK

www.manchesteruniversitypress.co.uk

British Library Cataloguing-in-Publication Data

A catalogue record for this book is available from the British Library

ISBN 0719038278 paperback

ISBN 9781526125637 Institutional

First edition published 1992 by Manchester University Press

Reprinted in paperback, with corrections 1993, 1996

First digital, on-demand edition produced by Lightning Source 2006

The publisher has no responsibility for the persistence or accuracy of URLs for any external or third-party internet websites referred to in this book, and does not guarantee that any content on such websites is, or will remain, accurate or appropriate. 